\title{
The Relationship Between Human Resource Management and Organizational Performance
}

\author{
Renata Peregrino de Brito ${ }^{\dagger}$ \\ St. Gallen University \\ Lucia Barbosa de Oliveira ${ }^{\Omega}$ \\ IBMEC - RJ
}

\begin{abstract}
This paper presents a theoretical and empirical analysis of the relationship between human resource management (HRM) and organizational performance. Theoretically, we discuss the importance of HRM for the development of resources and its impact on business performance. Empirically, we evaluated articles published on Brazilian academic journals that addressed such relationships. The results showed a lack of studies conducted at this intersection. From the universe of 2,469 articles, only $16(0.6 \%)$ sought to relate HRM and organizational performance. We observed a dominance of isolated HR practices, which does not consider HRM as a system, and of operational performance measures, relative to financial and efficiency variables. Most studies show a positive relationship between HRM practices and performance, in line with the literature. However, we point out some methodological issues, such as the difficulty of isolating the HR practices from its context, the failure to consider the temporality of this relationship, and the comparison between companies from different industries.
\end{abstract}

Keywords: Human resource management. Strategy. Organizational performance. Metaanalysis.

* Author for Correspondence:

$\dagger$. Doctor in Administration by the Getulio Vargas

$\Omega$ Doctor in Administration by the Coppead - UFRJ

Foundation (FGV-SP)

Link: St. Gallen University

Link: Professor and academic coordinator at Faculdade de

Economia e Finanças Ibmec-RJ

Address: Lore Sandozweg 23, Biel - 2503 - Suíça

E-mail: Renatap.brito@gmail.com

Address: Av. Pres. Wilson, 118, - Rio de Janeiro - RJ - Brazil

Phone:

CEP 20030-020

E-mail: lucia.oliveira@ibmecrj.br

Phone: 


\section{INTRODUCTION}

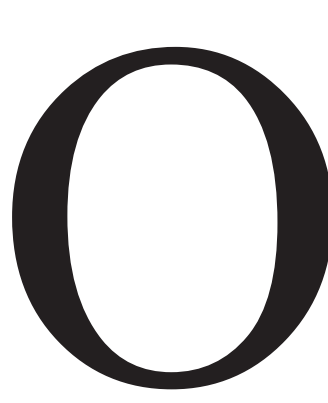

ne of the main themes in the field of business strategy concerns the competitiveness and determinants of organizational performance (BESANKO et al., 1996; GHEMAWAT, 2002). Amongst the main theoretical strands seeking to explain business competitiveness, the Resource Based View (RBV), which focuses on the development and exploitation of valuable, rare, and non-imitable resources, gives base to the hypothesis about the importance of human resource management (HRM) to companies' competitiveness (BARNEY, 1991; BARNEY; WRIGHT, 1998). Specialized human resources are valuable and potentially rare asthey detain tacit knowledge built by socially complex mechanisms. Imitating these resources is also challenging, since its relationship with organizational performance is uncertain and imprecise or, in other words, because they contain a causal ambiguity (BARNEY; WRIGHT, 1998; COFF, 1997).

Human resource management (HRM), as a key player in the creation and development of a highly productive workforce, lies in the center of the debate on the competitiveness of businesses (LEPAK et al., 2006). Practices that promote employee motivation and effort, knowledge, skills, and abilities, and opportunities for employee's contribution (JIANG et al., 2012) generate favorable conditions for the development of resources and capabilities that create value for organizations (BARNEY; WRIGHT, 1998), contributing to their performance and to the emergence of sustained competitive advantages (HUSELID, 1995; WRIGHT; MCMAHAN; MCWILLIAMS, 1994). This set of practices has been called, among other denominations, high-performance work systems (HPWS), following a line of study initiated by Huselid (1995). From this legacy, various studies tried to relate HRM systems or practices with organizational performance variables (COMBS et al., 2006; SHAW; PARK; KIM, 2013; WRIGHT et al., 2005). However, it is known that we are not dealing with a direct relation and of simple verification.

The study of organizational performance involves challenges regarding the interaction between the theoretical approach and the empirical observation of the concept (COMBS; CROOK; SHOOK, 2005). Organizational performance is a multidimensional and complex concept whose excessive simplification can prevent the assessment of management results (COMBS; CROOK; SHOOK, 2005; RICHARD et al., 2009; VENKATRAMAN; RAMANUJAM, 1986). On the one hand, the large number of variables used in the 
operationalization of performance leads to different results and a large variance in conclusions, limiting knowledge accumulation (BOYD; GOVE; HITT, 2005). On the other hand, the use of unique variables of profitability brings an oversimplification of a complex and multivariate construct (COMBS; CROOK; SHOOK, 2005; RICHARD et al., 2009). Furthermore, financial performance measures do not represent the operational performance of the company and are more subject to the process of value appropriation on the part of actors involved (COFF, 1999; CROOK et al., 2011). Therefore, to support research on organizational performance the choice of performance measures should not desregard a theoretical discussion about the adopted approach.

Given the acknowledged importance of HRM for organizational performance, this article makes a theoretical analysis on these subjects and assesses empirical studies that address the relationship between HRM and performance. In the theoretical framework, we discuss challenges and difficulties inherent to research in this field, such as the need for a broader assessment of organizational resources and other causal antecedents of performance.

In the empirical stage, we evaluated articles published in major national journals that sought, somehow, to address such relationships, detailing the characteristics of samples, methods and measures and of the variables used in the operationalization of the two constructs. Finally, we discuss the results and the evidence of the impact of HRM on strategic resources development and its effect on organizational performance.

\section{BUSINESS STRATEGY AND HUMAN RESOURCES}

The heterogeneity of the organizational performance can be explained by the choice and positioning in a given sector (PORTER, 1985), by the development of valuable, rare and nonimitable resources (BARNEY, 1991), or by the development of routines and dynamic capabilities (TEECE; PISANO; SHUEN, 1997). While the external analysis reveals the attractiveness of each industry, it is in the company's resources and capabilities that one can acknowledge the uniqueness of its attributes and explain differences in performance between companies of the same sector (BARNEY; ARIKAN, 2001).

The resource-based view (RBV) envisages the company as a collective of fungible resources, developed internally or in interaction with partners, in a singular and idiosyncratic manner to each company and interaction (BARNEY; ARIKAN, 2001). The time and social complexity involved in the development of resources are some of the attributes that makes them rare and difficulty to imitate (BARNEY, 1991). In a successful strategy, valuable resources are not easily replicated by competitors, because they are the result of a unique 
development path. In addition, as their relationship with performance is not clear or direct, there is a causal ambiguity between resources and performance (BARNEY, 1991; DIERICKX; COOL, 1989). Resources and capabilities bring focus to inside the organization and its interaction with a changing and unstable environment. Competitive advantage is set up within this business-environment interaction and the development of resources and responses superior to that of competitors.

According to the RBV, human resources of an organization can contribute to superior performance and become a source of sustainable competitive advantage as long as they are valuable, rare and difficult to imitate (BARNEY; WRIG, 1998HT). Human resources have the potential to contain these attributes if we consider the value of a highly skilled workforce, the relative scarcity of qualified professionals, and that the explicit and tacit knowledge of employees are built over time and through socially complex mechanisms (CROOK et al., 2011).

In this case, the role of human resources management would reside precisely in the construction and development of a workforce - also referred to as human assets (COFF, 1997) or human capital (CROOK et al., 2011) - competent, motivated and able to generate superior results (BARNEY; WRIGHT, 1998; COFF, 2002). This is called strategic human resources management, as discussed below.

\section{STRATEGIC MANAGEMENT OF HUMAN RESOURCES}

The literature on strategic human resources management (SHRM) is based on two fundamental principles. The first concerns the strategic importance of human resources, their competencies and behaviors, whilst the second refers to the role of human resource management practices in the development of these very resources (COLBERT, 2004; BECKER; GERHART, 1996).

Research on SHRM takes into account HR systems as a whole and their impact on the organization, as opposed to the traditional perspective, which assesses HR practices separately and considers their impact on individual performance (BECKER; HUSELID, 2006). This movement toward a macro or systemic vision was due to the need for greater clarity regarding the impact of the human resources function on organizational results (SUN; ARYEE; LAW, 2007). Such an approach also reflects the understanding that, in order to be more effective, HR policies and practices must be congruent with each other (horizontal alignment) and aim to achieve the strategic goals of the organization (vertical alignment) (DELERY; DOTY, 1996). 
With respect to empirical studies in the field of SHRM, the matter that still does not seem to have been fully understood concerns the set of HR practices that effectively would contribute to higher organizational performance. Delery and Doty (1996) highlight the existence of three different theoretical perspectives (universalist, contingent and configurational), each one with implicit assumptions in this regard.

According to the universalistic perspective, certain practices would always be superior to others, regardless of the company's strategic positioning. The concept of high-performance work systems or high commitment work systems seems to have emerged from this line of research. However there has been no consensus in relation to practices that should be included in these systems and, consequently, surveys have been conducted with different sets of practices (DELANEY; HUSELID, 1996; LEPAK et al., 2006), which makes it difficult for knowledge accumulation (JIANG et al., 2012). The contingency approach, best aligned with the premise of vertical alignment, assumes that HR practices should be consistent with other characteristics of the organization, including its strategies. Finally, the configurational perspective focuses on the identification of unique patterns of factors that would have a synergistic and superior effect, built theoretically from ideal types (DELERY; DOTY, 1996). Both contingent and configurational perspectives align with the RBV approach, as they understand HRM as a set of idiosyncratic resources used by the organization to achieve its strategic goals (BARNEY; WRIGHT, 1998).

In an attempt to identify dimensions or categories of practices that make up HPWS, the structure called skills-motivation-opportunity, originally proposed by Guest (1997), has been highlighted in literature. According to this framework, HR practices can be evaluated by their impact on employees' skills, their motivation and effort, and the opportunities they have to contribute (JIANG et al., 2012). Table 1 shows examples of HR practices associated with each of these categories.

\begin{tabular}{|l|l|}
\hline Dimensions & HR practices \\
\hline Competencies & Recruitment and selection; training, development and education. \\
\hline Motivation and effort & $\begin{array}{l}\text { Evaluation of performance, rewards, incentives, benefits, promotion and career } \\
\text { development, and job security. }\end{array}$ \\
\hline $\begin{array}{l}\text { Opportunities to } \\
\text { contribute }\end{array}$ & $\begin{array}{l}\text { Workflow design, work teams, employee involvement policies, sharing information } \\
\text { and formal systems of complaints and claims. }\end{array}$ \\
\hline
\end{tabular}

Table 1 - Dimensions of HR practices

Source: Jiang et al. (2012). 
Jiang et al. (2012) also point out that little is known about the interrelationships between the various practices, highlighting the possibility of additive, synergistic or substitute effects. In the first case, the practices have independent effects, so that each one contributes to the effectiveness of the system. If the relationship is substitutive, it implies that one practice may be replaced by another without losses, and that one of them is generating higher operating costs without adding benefits. Finally, the relationship between practices is synergistic when one contributes to enhancing the effectiveness of the other.

In light of these practical and methodological issues, and despite the evidence of the positive impact of human resource management on different organizational results, some aspects of this relationship still lack clarity (JIANG et al., 2012). Many researchers use the term "black box" to highlight the difficulty of assessing the link between HRM and organizational performance (COLLINS; SMITH, 2006; SUN; ARYEE; LAW, 2007).

\section{ORGANIZATIONAL PERFORMANCE}

Studies on SHRM emphasize the role of human resources practices in achieving organizational objectives (COMBS et al., 2006; FERGUSON; REIO JR., 2010; HUSELID; JACKSON; SCHULER, 1997; OLIVEIRA; OLIVEIRA, 2011; WRIGHT; MCMAHAN, 1992). However, one of the key challenges of understanding organizational performance lies in the alignment of its theoretical definition, methodological design and research objectives.

Since organizational performance is a multidimensional concept, it seeks to measure companies' success in achieving the objectives proposed for different stakeholders in a given period (RICHARD et al., 2009). The various dimensions of organizational performance seek to encompass the diversity of interests in the company's success. One of the most influential approaches states that organizational performance is made up of three dimensions that can be considered as spheres that superimpose and complement each other (VENKATRAMAN; RAMANUJAM, 1986). The wider dimension of organizational performance would be organizational effectiveness, including economic and social goals that takes into consideration the company's relationship with society and its stakeholders. The operational dimension encompasses aspects such as technology, innovation, productivity and quality, and mediates the relationship between the company's resources and its financial performance. Finally, the financial dimension incorporates aspects of financial returns, market value and growth (COMBS; CROOK; SHOOK, 2005; VENKATRAMAN; RAMANUJAM, 1986).

Far from a consensus, the debate on organizational performance recognizes the existence of different approaches and metrics. Most of authors recognize the importance of 
linking performance measures to a theoretical approach and even to a greater construct that explains the strategic advantage (COMBS; CROOK; SHOOK, 2005; RICHARD et al., 2009; VENKATRAMAN; RAMANUJAM, 1986).

\section{RELATIONSHIP BETWEEN HRM AND PERFORMANCE}

The main premise of studies on SHRM is that human resource management practices are causal antecedents of performance (BARNEY; WRIGHT, 1998; HUSELID, 1995). Therefore, to analyze the causal relationship among constructs, it is necessary to evaluate longitudinal data. Furthermore, due to the very nature of the process by which people management practices develop resources and capabilities that impact performance, it is argued that there is a maturation period for the results to be observable. Therefore, it is recommended the observation of longitudinal data, in a period compatible with the development of resources, and a lagged analysis between cause and effect (WRIGHT et al., 2005).

Another important aspect of performance evaluation is in its hierarchical nature, with different levels of analysis or spheres of influence: business, industry and institutional context (MCGAHAN; PORTER, 1997). The evaluation of superior performance depends on the competitive environment in which the company is inserted. Similarly, the effect of investments in human resources depends on the context and the level of expertise of human capital (CROOK et al., 2011). The more human capital-intensive sectors demand more investments, whilst less intensive ones may seek competitiveness from other strategic factors (SHAW; PARK; KIM, 2013). Seen in these terms, results from HRM analysis between sectors with different specificities of resources cannot be comparable (CROOK et al., 2011).

Finally, it is important to consider that the relationship between investments in HRM and performance is mediated by resources and capabilities generated in the process. This aspect can be even more relevant when one observes only the financial performance of the organization. This is because the value created may not revert into superior profitability if appropriated by transaction partners (COFF, 1999). In the bargaining process for the value created, employees increase their bargaining power as they become more specialized and not easily replaceable (COFF, 1999). In addition, managers are recognized as actors in privileged condition of appropriating value, given their access to important information (COFF, 1999; COFF; LEE, 2003). The influence of employees and managers in the process of distribution of the value created has an impact on the costs of the company and, consequently, on its profitability (BLYLER; COFF, 2003). In this sense, the relationship between HRM and 
operating performance can be more easily observed, both from the direct relationship between the two concepts and the fact that the operational performance precedes the process of appropriation (COMBS et al., 2006; CROOK et al., 2011). Financial variables, however, are more impacted by the process of appropriation and may not reflect the value created by the resources.

Taking into consideration the theoretical and methodological challenges presented here, in the second stage of this work, we sought to evaluate, by means of a meta-study, how the relationship between human resource management and organizational performance has been addressed in the main Brazilian publications in the field of administration.

\section{METHODOLOGICAL PROCEDURES}

The term meta-analysis, according to Hedges (1992), was introduced by Gene Glass in 1976 and defined as the analysis of statistical results from different studies in order to reach general conclusions. Meta-analysis techniques presuppose the use of reported correlations in studies for the subsequent calculation of the average correlations weighted by the size of the sample (HUNTER; SCHMIDT, 2004). In this study, given the limited number of quantitative studies and the unavailability of data, such as correlation coefficients of variables, we chose a qualitative approach, which allowed the inclusion of qualitative results, and characterized the study as a meta-study (PATTON, 2005).

For this meta-study, we considered all articles published in all 13 national journals within the area of Business Administration with a rating equal to or greater than B1 in the Capes's (Higher Education Personnel Improvement Coordination) Qualis system of 2012: Brazilian Administration Review, Brazilian Business Review, Cadernos EBAPE.BR, Gestão \& Produção, Organizações \& Sociedade, RAUSP, Revista Brasileira de Gestão de Negócios, Revista de Administração Contemporânea, Revista de Administração de Empresas, Revista de Administração e Contabilidade da Usinos, Revista de Administração e Inovação, Revista de Administração Mackenzie and Revista de Ciências da Administração. It was further established that the analysis period would comprise the years from 2007 to 2012.

The process of selecting articles was done in four stages. In the first stage, all the 2469 published articles in the selected journals were identified. In the second stage, we filtered the articles by the identification of keywords in titles and abstracts. The choice of keywords, presented in table 2, was based on bibliographical review of both themes. The keywords were also translated into English and Spanish to search in articles written in these languages. 760 
articles were identified (31\% out of the total) containing words related to HRM and organizational performance simultaneously.

\begin{tabular}{|c|l|}
\hline HRM & $\begin{array}{l}\text { HR, Human resources, Human Capital, Personnel Management, HR Practices and Policies, HR } \\
\text { Development, Remuneration, Strategic Remuneration, Remuneration Policies and Practices, } \\
\text { Management by Competencies, Retention, Motivation, Training and Development, } \\
\text { Recruitment and Selection, Commitment, Organizational Learning, Leadership, Job } \\
\text { Satisfaction, Career and Management Capacity. }\end{array}$ \\
\hline $\begin{array}{c}\text { Organizational } \\
\text { Performance }\end{array}$ & $\begin{array}{l}\text { Financial Performance, Business Performance, Organizational Performance, Operational } \\
\text { Performance, Organizational Results, Results, Performance, Competitive Advantage, Strategy, } \\
\text { Competitive Strategy, Organizational Strategy, Strategic Management, Strategic Behavior, } \\
\text { Organizational Behavior, Organizational Effectiveness, Growth, Productivity and Profitability. }\end{array}$ \\
\hline
\end{tabular}

Table 2 - keywords for triage of articles

In the third stage, we read the abstracts of the articles identified in the previous stage, in order to identify adherence with the objective of the study. In this process, we discarded the papers that mentioned keywords only tangentially - in the contextualization of the study, for example - or when these had different meanings. For example, "employed" can refer to an employee of an organization or be a synonym of "used". Finally, 66 articles were selected for the final evaluation stage, which consisted in integrally reading them.

Table 3 - Published, Filtered and Selected Articles

\begin{tabular}{|l|c|c|c|c|}
\hline \multirow{2}{*}{ Journal } & Stage 1 & Stage 2 & Stage 3 & Stage 4 \\
\cline { 2 - 5 } & Published & Filtered & $\begin{array}{c}\text { Initial } \\
\text { selection }\end{array}$ & $\begin{array}{c}\text { Final } \\
\text { selection }\end{array}$ \\
\hline Brazilian Administration Review (BAR) & & 9 & - & - \\
\hline Brazilian Business Review (BBR) & 128 & 42 & 2 & 1 \\
\hline Cadernos EBAPE.BR & 117 & 68 & 2 & 1 \\
\hline Gestão \& Produção (G\&P) & 236 & 111 & 13 & 2 \\
\hline Organizações \& Sociedade (O\&S) & 325 & 63 & 2 & - \\
\hline RAUSP & 221 & 47 & 4 & - \\
\hline Revista Brasileira de Gestão de Negócios (RBGN) & 139 & 68 & 3 & 1 \\
\hline Revista de Adm. Contemporânea (RAC) & 240 & 71 & 8 & 3 \\
\hline Revista de Adm. de Empresas (RAE) & 155 & 28 & 2 & 2 \\
\hline Revista de Adm. Contab. da Usinos (Base) & 120 & 38 & - & - \\
\hline Revista de Adm. e Inovação (RAI) & 202 & 80 & 12 & 4 \\
\hline Revista de Adm. Mackenzie (RAM) & 256 & 88 & 15 & 2 \\
\hline Revista de Ciências da Administração (RCA) & 170 & 47 & 3 & - \\
\hline TOTAL & 2469 & 760 & 66 & 16 \\
\hline
\end{tabular}


In the fourth and final stage, all the 66 studies were fully read by the authors, and it was verified that only $16(0.6 \%$ out of the total) effectively proposed to analyze the relationship between human resource management and organizational performance, from a qualitative or quantitative empirical approach. Table 1 contains data relating to the process of filtering and selection.

\section{ANALYSIS AND DISCUSSION OF RESULTS}

In the 16 selected articles, we found both quantitative (10) and qualitative (6) approaches. As for the method, the quantitative studies made use of structural equation models (4), linear regression (4), ANOVA (1), correlation analysis (1) and exploratory factor analysis (1). The six qualitative studies adopted the case study method. The samples varied both in number of companies as well as in relation to their sectors. In the analysis that follows, we discuss HRM topics, constructs and variables, approaches to organizational performance and, subsequently, the relationship between HRM and organizational performance.

\subsection{HUMAN RESOURCES MANAGEMENT}

The analysis of the constructs and variables of HR was initially divided into HRM practices and results, that is, resources developed by HRM. In the HRM practices analysis, we adopted the categorization proposed by Jiang et al. (2012), according to which the organization's performance would be impacted by the performance of employees, which in turn would be explained from the impacts of HR practices on their levels of competence, motivation and effort, and opportunity to contribute.

As shown in Table 3, nine studies addressed HR practices - four related to employees' skills, two concerning the creation of an environment propitious to contribution and only three focused on the set of HR practices.

The three papers reviewing the set of HR practices and their impact on different dimensions of performance are in line with the literature on high-performance work systems, according to which HRM should be evaluated as a whole (BECKER; HUSELID, 2006; COLBERT, 2004; LEPAK et al., 2006). However, we should point out that the operationalization of the construct proved to be relatively simplistic. In two of them, a single item measured the effectiveness of such practices and, in the third paper, the questionnaire consisted of only five items that assessed recruitment practices, training, performance appraisal and reward systems. 
Five studies did not assess HR practices, but variables and constructs that typically are impacted by HRM, such as resources or organizational capabilities, namely: human capital, learning culture, knowledge management, learning orientation and organizational values. Finally, two articles, both qualitative, addressed HR practices as well as resources or capacities generated by HR actions.

\begin{tabular}{|c|c|c|}
\hline Dimension & Variables & Article \\
\hline \multicolumn{3}{|l|}{ HR Practices } \\
\hline \multirow{4}{*}{ Competencies } & Volume of investments in $\mathrm{R} \$(\mathrm{BRL})$ & El-Kouba et al. (2009) \\
\hline & $\begin{array}{l}\text { R\&D employees' educational level (number of masters and } \\
\text { PhDs); employees' educational level (IT training); company } \\
\text { support for training. }\end{array}$ & $\begin{array}{l}\text { Gomel and Sbragia } \\
\text { (2011) }\end{array}$ \\
\hline & $\begin{array}{l}\text { Program's effects on the individual, the team and the } \\
\text { management of the company. }\end{array}$ & Perin et al.(2009) \\
\hline & Performance assessment and skills development. & $\begin{array}{l}\text { Ubeda and Santos } \\
(2008)\end{array}$ \\
\hline \multirow{2}{*}{$\begin{array}{l}\text { Opportunity to } \\
\text { contribute }\end{array}$} & $\begin{array}{l}\text { Employee-management relationship; responsibility, freedom, } \\
\text { decision making, control exercise for managers; use of power. }\end{array}$ & $\begin{array}{l}\text { Kirjavainen et al. } \\
(2010)\end{array}$ \\
\hline & Confidence, commitment; teamwork. & $\begin{array}{l}\text { Moori and Domenek } \\
\text { (2007) }\end{array}$ \\
\hline \multirow{3}{*}{ Set of Practices } & $\begin{array}{l}\text { Recruitment; training; performance evaluation; reward system; } \\
\text { benefits system. }\end{array}$ & Jabbour et al. (2012) \\
\hline & $\begin{array}{l}\text { Ability to keep staff well trained and motivated to work (single } \\
\text { item). }\end{array}$ & $\begin{array}{l}\text { Maciel and Camargo } \\
(2009)\end{array}$ \\
\hline & $\begin{array}{l}\text { Effectiveness of HR management in relation to competition } \\
\text { (single item). }\end{array}$ & $\begin{array}{l}\text { Perin, Sampaio and } \\
\text { Hooley (2007) }\end{array}$ \\
\hline \multicolumn{3}{|c|}{ HR / Resource Results } \\
\hline Human Capital & $\begin{array}{l}\text { Relationship between workers, employer-employee relationship, } \\
\text { turnover, problems when someone leaves the company, difficulty } \\
\text { in assessing the consequences of decisions. }\end{array}$ & $\begin{array}{l}\text { Ferreira and Martinez } \\
(2011)\end{array}$ \\
\hline Learning culture & $\begin{array}{l}\text { Opportunities for continuous learning; questioning and dialogue; } \\
\text { collaboration and team learning, systems to capture and share } \\
\text { learning; delegation of power and responsibility; development of } \\
\text { the organization's systemic vision; stimulating strategic } \\
\text { leadership towards learning. }\end{array}$ & $\begin{array}{l}\text { Menezes, Guimarães } \\
\text { and Bido (2011) }\end{array}$ \\
\hline $\begin{array}{l}\text { Knowledge } \\
\text { management }\end{array}$ & $\begin{array}{l}\text { Informality in the communication, horizontal hierarchical } \\
\text { structure, teamwork, quality of leadership, support from senior } \\
\text { management. }\end{array}$ & Oliveira et al. (2012) \\
\hline $\begin{array}{l}\text { Learning } \\
\text { Orientation }\end{array}$ & Commitment to learning; shared vision; open minded. & $\begin{array}{l}\text { Abbade, Zanini and } \\
\text { Souza (2012) }\end{array}$ \\
\hline $\begin{array}{l}\text { Organizational } \\
\text { values }\end{array}$ & $\begin{array}{l}\text { Respecting stakeholders; entertainment for employees; competent } \\
\text { performance; prestige. }\end{array}$ & $\begin{array}{l}\text { Melo and Domenico } \\
(2012)\end{array}$ \\
\hline \multicolumn{3}{|c|}{ Practices and Results } \\
\hline $\begin{array}{l}\text { Practices of T\&D } \\
\text { Results of R\&S }\end{array}$ & $\begin{array}{l}\text { Practices: training expenditures as a proportion of the company's } \\
\text { revenue. } \\
\text { Results: professionals (different academic levels) working in } \\
\text { R\&D. }\end{array}$ & $\begin{array}{l}\text { Santos, Basso and } \\
\text { Kimura (2012) }\end{array}$ \\
\hline $\begin{array}{l}\text { HR management } \\
\text { HR results }\end{array}$ & $\begin{array}{l}\text { Practices: training, encouraging cooperation, teamwork. } \\
\text { Results: turnover. }\end{array}$ & $\begin{array}{l}\text { Zen and Fracasso } \\
(2012)\end{array}$ \\
\hline
\end{tabular}

Table 4 - Human resource management variables 


\subsection{ORGANIZATIONAL PERFORMANCE}

As shown in table 4, 26 performance variables were identified in the 16 selected articles, with the majority being of operational performance (12 articles), followed by financial performance variables (five articles). Only three articles treated both dimensions concomitantly. This result differs from that found in international studies, in which financial performance variables are more frequent (COMBS et al., 2006; CROOK et al., 2011). The use of operational performance variables best captures the impact of HRM and resources on the performance, since the operational performance is a direct mediator of this relationship and it does not suffer from the impact of the appropriation of value (COMBS et al., 2006; WRIGHT et al., 2005). The combination of financial and operational variables, however, allows both the evaluation of HRM results as well as the impact of value appropriation in the process.

The most common variables were innovation and profitability, but, in general, we verified a low repetition of variables and of the metrics employed. The use of different psychometric scales (seven articles) and subjective analysis (five articles) for performance variables reduces the comparability of results between the studies. Among the studies, there was also the use of metrics that do not correspond to the organization as unit of analysis (teams, for example) and, for the purposes of this study, we did not considered these metrics.

Despite arguing that HR practices and resulting resources can lead to competitive advantage, few studies presented analyses of competitiveness. The analysis of the effects of HRM on the performance of the organization does not allow conclusions about the competitiveness of practices or their capacity to lead to competitive advantage. Finally, we note that the operationalization of the organizational performance construct is not preceded by a theoretical definition, leading to an obscure process of choice of variables. Variables from different dimensions are beneficial, but a convergent validity analysis is required. Moreover, it should be avoided variables of superimposing dimensions and measures of low theoretical or empirical relevance (COMBS; CROOK; SHOOK, 2005; RICHARD et al., 2009).

\begin{tabular}{|c|c|c|}
\hline Variables & $\begin{array}{l}\text { Method/ } \\
\text { measurement }\end{array}$ & Studies \\
\hline \multicolumn{3}{|l|}{ Financial Performance } \\
\hline $\begin{array}{l}\text { Profitability, Return on Assets, Return on } \\
\text { Equity, Return on Sales and Operating } \\
\text { Margin }\end{array}$ & $\begin{array}{l}\text { Psychometric scale } \\
\text { and secondary data }\end{array}$ & $\begin{array}{l}\text { Abbade, Zanini and Souza (2012); } \\
\text { Santos, Basso and Kimura (2012); } \\
\text { Maciel and Camargo (2009) }\end{array}$ \\
\hline Sales growth & Psychometric scale & $\begin{array}{l}\text { El-Kouba et al. (2009); Maciel and } \\
\text { Camargo (2009) }\end{array}$ \\
\hline Performance in relation to competitors & Psychometric scale & Maciel and Camargo (2009) \\
\hline
\end{tabular}




\begin{tabular}{|c|c|c|}
\hline Revenues & Psychometric scale & El-Kouba et al. (2009) \\
\hline Export volume & Secondary data & Gomel and Sbragia (2011) \\
\hline Satisfaction with respect to investment & Psychometric scale & Maciel and Camargo (2009) \\
\hline \multicolumn{3}{|l|}{ Operational Performance } \\
\hline $\begin{array}{l}\text { New products (development, introduction } \\
\text { and launching) }\end{array}$ & $\begin{array}{l}\text { Subjective and } \\
\text { psychometric scale }\end{array}$ & $\begin{array}{l}\text { Kirjavainen et al. (2010); Perin, } \\
\text { Sampaio and Hooley (2007); Oliveira et } \\
\text { al. (2012); Zen and Fracasso (2012) }\end{array}$ \\
\hline Time-to-market & Psychometric scale & $\begin{array}{l}\text { Jabbour et al. (2012); Menezes, } \\
\text { Guimarães and Bido (2011). }\end{array}$ \\
\hline Productivity & Psychometric scale & $\begin{array}{l}\text { Ferreira and Martinez (2011); Menezes, } \\
\text { Guimarães and Bido (2011) }\end{array}$ \\
\hline Flexibility & $\begin{array}{l}\text { Subjective and } \\
\text { psychometric scale }\end{array}$ & Perin et al. (2009); Jabbour et al. (2012) \\
\hline $\begin{array}{l}\text { Success of new products (relevance in total } \\
\text { revenues) }\end{array}$ & Psychometric scale & $\begin{array}{l}\text { Perin, Sampaio and Hooley (2007); Zen } \\
\text { and Fracasso (2012) }\end{array}$ \\
\hline Operational cost & Psychometric scale & Jabbour et al. (2012) \\
\hline Customer loyalty & Psychometric scale & El-Kouba et al. (2009) \\
\hline Number of customers and contracts & Psychometric scale & El-Kouba et al. (2009) \\
\hline Meeting deadlines & Psychometric scale & Jabbour et al. (2012) \\
\hline Time of response to complaints & Psychometric scale & Menezes, Guimarães and Bido (2011) \\
\hline Inventory reduction & Subjective & Moori and Domenek (2007) \\
\hline Reliability in the delivery of products & Subjective & Moori and Domenek (2007) \\
\hline Innovation Pioneering & Psychometric scale & Perin, Sampaio and Hooley (2007) \\
\hline Intellectual production & Subjective & Ubeda and Santos (2008) \\
\hline Patents & Subjective & Zen and Fracasso (2012) \\
\hline Transfer of technology & Subjective & Ubeda and Santos (2008) \\
\hline Growth of activities & Psychometric & Maciel and Camargo (2009) \\
\hline \multicolumn{3}{|l|}{ Others } \\
\hline Achieved goals (financial and operational) & $\begin{array}{l}\text { Secondary data and } \\
\text { psychometric scale }\end{array}$ & $\begin{array}{l}\text { Melo and Domenico (2012); El-Kouba } \\
\text { et al. (2009) }\end{array}$ \\
\hline Survival & Psychometric & Maciel and Camargo (2009) \\
\hline Success in business & Psychometric & Maciel and Camargo (2009) \\
\hline
\end{tabular}

Table 5 - Organizational performance variables

\subsection{RELATIONSHIP BETWEEN HRM AND PERFORMANCE}

The main focus of this study was the analysis of the bivariate relationship between HRM and organizational performance, in the form of HR policies and practices or of resources and capabilities generated by these. In eleven of the selected articles, this relationship was positive, and in the eight studies that promoted statistical tests, they were significant - see Appendix 1. Five studies showed no conclusive results, whether by lack of segregation of practices between organizations/projects of low and high performance, or for 
the non-consummation of empirical test among the constructs (FRACASSO; ZEN, 2012; KIRJAVAINEN et al., 2010; OLIVEIRA et al., 2012; SANTOS; BASSO; KIMURA, 2012; UBEDA; SANTOS, 2008).

The positive result among the constructs corroborates to the theoretical discussions about the ability of HRM to develop resources that create value for businesses (BARNEY; WRIGHT, 1998; BECKER; GERHART, 1996) and to the empirical studies that demonstrate the positive relationship between HRM and organizational performance (COMBS et al., 2006; CROOK et al., 2011; OLIVEIRA; OLIVEIRA, 2011).

However, it is necessary to discuss some relevant aspects of the relationship between these constructs, because by ignoring aspects of endogeneity in the choice of HRM investments, the resulting parameters and coefficients may be biased (ANTONAKIS et al., 2010). Therefore, we discuss aspects that require further investigation.

The first observation, which constitutes a contribution of this study, concerns the analysis of competitiveness of HRM in relation to other resource development practices in companies. There is a wide range of resources and capabilities that can be identified as antecedents to performance, but not all are able to lead to superior performance (NEWBERT, 2007). The positive result of practices and resources on the performance of a single company does not allow conclusions about their competitiveness, as those practices and resources may simply be competitive parity factors. Furthermore, as the relevance of resources also varies across different sectors and industries, studies that mix different industrial sectors do not allow acknowledging whether the strategy is idiosyncratic to the company or a self-selection process, inherent in the industry. Among the eight studies with positive and significant results, three studies combine different sectors and none of them use control variables to deal with the effect of omitted variables, aspects that limit conclusions on the effectiveness of HRM practices.

The analysis of the competitiveness of resources also demands the observation of performance measures in accordance with their potential for appropriation. This aspect is particularly relevant in the analysis of HR practices, because managers and employees have great ability to identify value, generating an information asymmetry that favors them in the process of appropriation (BLYLER, COFF, 2003; COFF, 1999). With time, this process of appropriation can decrease shareholders' interest in investing in human resources, given its low capacity of appropriation, as well as increase employee turnover potential (SHAW; 
PARK; KIM, 2013). This important aspect to business management practitioners is not contemplated in the studies we analyzed.

The third contribution of this article is in the observation of the longitudinal aspect of the relationship between HRM and performance constructs. As an antecedent to the development of resources, investment in HR may involve only negative results, that is, costs, at a first moment. However, it is expected that, over time, such investments will generate superior human capital that will positively affect organizational performance. In this sense, the analysis of the relationship between HRM and performance would be ideally made in longitudinal studies, or in situations of recognized maturity of HR practices. Out of the studies analyzed, only three showed longitudinal approaches in case studies and two introduced longitudinal comparison variables, like sales growth, but none of them worked with lagged variables analysis.

Finally, the fourth contribution concerns the possibility of isolating HRM practices to analyze its impact on performance. On the one hand, isolated practices do not depict broader constructs, such as high-performance work systems (BECKER; HUSELID, 2006; DELERY; DOTY, 1996). On the other hand, the non-observation of the larger context of the practices also does not refute the hypothesis that there are superior HRM systems or even other omitted resources and variables that may lead to superior performance. Without a more comprehensive analysis of HRM, including the different interrelations between the practices (JIANG et al., 2012) and their impact on the dimensions of performance, a conclusion about the strategic importance of human resources for the organization becomes questionable.

\section{FINAL CONSIDERATIONS}

The aim of this study was to analyze how the Brazilian scientific production deals with the relationship between human resource management and organizational performance. Its relevance is in the acknowledgment of the importance of people in the development of resources and capabilities (BARNEY; WRIGHT, 1998; HELFAT; PETERAF, 2003) and in the creation of sustainable competitive advantages (BARNEY, 1991). As a limitation, we highlight the time frame and the initial screening, done only from the abstracts.

The literature review showed a wide range of relations between HRM practices and operating and financial performance of organizations (HUSELID, 1995; WRIGHT et al., 2005), as well as practical and methodological issues. The empirical part of the study showed that the subject is not yet dominant in national production and that there are few attempts to 
measure the relationship between these constructs. The results also showed gaps in the design and implementation of researches.

With regard to performance measures, there are important deficiencies in the measurement of variables, in the combination of more than one dimension of performance, in the comparative analysis between companies, and in the temporal analysis of performance. With respect to HRM, we verified the concomitant use of variables related to HR practices and results, which is not recommended (JIANG et al., 2012). We also identified the use of a wide range of variables, a point also noted in the international literature (DELANEY; HUSELID, 1996) and that has been the target of criticism, since it imposes limitations on knowledge accumulation (BOYD; GOVE; HITT, 2005).

In the analysis of the few studies that seek to assess the impact of HRM on performance, we observed a dominance of positive results, in line with evidence found in the international literature (CHADWICK; SUPER; KWON, 2014; COMBS et al., 2006; CROOK et al., 2011; RAZOUK, 2011; SUN; ARYEE; LAW, 2007). However, considering the dispersion of variables and the methodological issues, we could not draw more thorough conclusions about the Brazilian reality, suggesting a fruitful field for future research.

\section{REFERENCES}

ABBADE, E. B.; ZANINI, R. R.; SOUZA, A. M. Orientação para aprendizagem, orientação para mercado e desempenho organizacional: evidências empíricas. Revista de Administração Contemporânea, v. 16, n. 1, p. 2012.

ANTONAKIS, J. et al., On Making Causal Claims: A review and recommendations. The Leadership Quarterly, v. 21, n. 6, p. 1086-1120, 2010.

BARNEY, J. B. Firm resources and sustained competitive advantage. Journal of Management, v. 17, n. 1, p. 99-120, 1991.

BARNEY, J. B., ARIKAN, A. M. The resource-based view: origins and implications. In: hitt, M. A.; FREEMAN, R. E.; HARRISON, J. S. (Orgs.). The blackwell handbook of strategic management. Oxford: Blackwell Publishers Ltd., 2001.

BARNEY, J. B.; WRIGHT, P. M. On becmoming a strategic partner: the role of human resources in gaining competitive advantage. Human Resource Management, v. 37, n. 1, p. 31, 1998.

BECKER, B. E.; GERHART, B. The impact of human resource management on organizational performance: progress and prospects. Academy of Management Journal, v. 39, n. 4, p. 779-801, 1996.

BECKER, B. E.; HUSELID, M. A. Strategic human resources management: where do we go from here? Journal of Management, v. 32, n. 6, p. 898-925, 2006. 
BESANKO, D. et al. Economics of strategy. Hoboken: NJ, John Wiley \& Sons, Inc, 1996.

BLYLER, M.; COFF, R. W. Dynamic capabilities, social capital, and rent appropriation: ties that split pies. Strategic Management Journal, v. 24, n. 7, p. 677-686, 2003.

BOYD, B. K.; GOVE, S.; HITT, M. A. Construct measurement in strategic management research: illusion or reality? Strategic Management Journal, v. 26, n. 3, p. 239, 2005.

CHADWICK, C.; SUPER, J. F.; KWON, K. Resource orchestration in practice: CEO emphasis on SHRM, commitment-based HR systems, and firm performance. Strategic Management Journal, 2014.

COFF, R. W. Human assets and management dilemmas: coping with hazards on the road to resource-based theory. Academy of Management Review, v. 22, n. 2, p. 374-402, 1997.

When competitive advantage doesn't lead to performance: the resource-based view and stakeholder bargaining power. Organization Science, v. 10, n. 2, p. 119-133, 1999.

Human capital, shared expertise, and the likelihood of impasse in corporate acquisitions. Journal of Management, v. 28, n. 1, p. 107-128, 2002.

COFF, R. W.; LEE, P. M. Insider trading as a vehicle to appropriate rent from R\&D. Strategic Management Journal, v. 24, n. 2, p. 183-190, 2003.

COLBERT, B. A. The complex resource-based view: implications for theory and practice in strategic human resource management. Academy of Management Review, v. 29, n. 3, p. 341-358, 2004.

COLLINS, C. J.; SMITH, K. G. knowledge exchange and combination: the role of human resource practices in the performance of high-technology firms. Academy of Management Journal, v. 49, n. 3, p. 544-560, 2006.

COMBS, J. G.; CROOK, R. T.; SHOOK, C. L. The dimension of organizational performance and its implications for strategic management research. In: KETCHEN, D. J.; BERGH, D. D. (Orgs.). Research Methodology in Strategy and Management. San Diego: Elsevier, 2005.

COMBS, J. G. et al. How much do high-performance work practices matter? A meta-analysis of their effects on organizational performance. Personnel Psychology, v. 59, n. 3, p. 501-528, 2006 .

CROOK, T. R. et al. Does human capital matter? A meta-analysis of the relationship between human capital and firm performance. Journal of Applied Psychology, v. 96, n. 3, p. 443-456, 2011.

DELANEY, J. T.; HUSELID, M. A. the impact of human resource management practices on perceptions of organizational performance. Academy of Management Journal, v. 39, n. 4, p. 949-969, 1996.

DELERY, J. E.; DOTY, D. H. Modes of theorizing in strategic human resource management: tests of universalistic, contingency, and configurational performance predictions. Academy of Management Journal, v. 39, n. 4, p. 802-835, 1996. 
DIERICKX, I.; COOL, K. Asset stock accumulation and sustainability of competitive advantage. Management Science, v. 35, n. 12, p. 1504-1513, 1989.

EL-KOUBA, A. et al. Programas de desenvolvimento comportamental: influências sobre os objetivos estratégicos. RAE-Revista de Administração de Empresas, v. n. p. 295-308, 2009.

FERGUSON, K. L.; REIO JR., T. G. human resource management systems and firm performance. Journal of Management Development, v. 29, n. 5, p. 471-494, 2010.

FERREIRA, A. I.; MARTINEZ, L. F. intellectual capital: perceptions of productivity a and investment. Revista de Administração Contemporânea, v. 15, n. 2, p. 249-260, 2011.

PERIN, M. G.; SAMPAIO, C. H.; HOOLEY, G. Impacto dos recursos da empresa na performance de inovação. RAE-Revista de Administração de Empresas, v. 47, n. 4, p. 113, 2007.

GHEMAWAT, P. competition and business strategy in historical perspective. Business History Review, v. 76, n. 1, p. 37-74, 2002.

GOMEL, M. M.; SBRAGIA, R. A competitividade da indústria brasileira de software ea influência da capacitação tecnológica no desempenho exportador. Revista de Administração e Inovação, v. 8, n. 1, p. 2011.

GUEST, D. E. Human resource management and performance: a review and research agenda. International Journal of Human Resource Management, v. 8, n. 3, p. 263-276, 1997.

HEDGES, L. V. Meta-analysis. Journal of Educational and Behavioral Statistics, v. 17, n. 4, p. 279-296, 1992.

HELFAT, C. E.; PETERAF, M. A. The dynamic resource-based view: capability lifecycles. Strategic Management Journal, v. 24, n. 10, p. 997-1010, 2003.

HUNTER, J. E.; SCHMIDT, F. L. Methods of meta-analysis: correcting error and bias in research findings. Sage, 2004.

HUSELID, M. A. The impact of human resource management practices on turnover, productivity, and corporate financial performance. Academy of Management Journal, v. 38, n. 3, p. 635-672, 1995.

HUSELID, M. A.; JACKSON, S. E.; SCHULER, R. S. Technical and strategic human resources management effectiveness as determinants of firm performance. Academy of Management Journal, v. 40, n. 1, p. 171-188, 1997.

JABBOUR, C. J. C. et al. Gestão de recursos humanos e desempenho operacional: evidências empíricas. Gestão \& Produção, v. 19, n. p. 347-360, 2012.

JIANG, K. et al. How does human resource management influence organizational outcomes? A meta-analytic investigation of mediating mechanisms. Academy of Management Journal, v. 55, n. 6, p. 1264-1294, 2012. 
KIRJAVAINEN, S. et al. O impacto da liderança, gestão e poder em uma organização internacional intensiva em conhecimento. Cadernos EBAPE.BR, v. n. 2, p. 339 a 352, 2010.

LEPAK, D. P. et al. A conceptual review of human resource management systems in strategic human resource management research. Research in personnel and human resources management, v. 25, n. p. 217-271, 2006.

MACIEL, C. O.; CAMARGO, C. Competências e desempenho de organizações varejistas: um estudo na visão baseada em recursos. Revista Brasileira de Gestão de Negócios, v. 11, n. 32, p. 2009.

MCGAHAN, A.; PORTER, M. E. How much does industry matter, really? Strategic Management Journal, v. 18, n. 4, p. 15-30, 1997.

MELO, W. F.; DOMENICO, S. M. R. A influência dos valores organizacionais no desempenho de agências bancárias. Revista de Administração Contemporânea, v. 16, n. 1, p. 137-156, 2012.

MENEZES, E. A. C.; GUIMARÃES, T. D. A.; BIDO, D. D. S. Dimensões da aprendizagem em organizações: validação do dimensions of the learning organization questionnaire (DLOQ) no contexto brasileiro. Revista de Administração Mackenzie, v. 12, n. 2, p. 4-29, 2011.

MOORI, R. G.; DOMENEK, A. C. Análise exploratória da colaboração dos funcionários e do desempenho do planejamento colaborativo na Klabin S. A. Revista de Administração Mackenzie, v. 8, n. 2, p. 2007.

NEWBERT, S. L. Empirical research on the resource-based view of the firm: an assessment and suggestions for future research. Strategic Management Journal, v. 28, n. 2, p. 121-146, 2007.

OLIVEIRA, A. M. B. D.; OLIVEIRA, A. J. D. Gestão de recursos humanos: uma metanálise de seus efeitos sobre desempenho organizacional. Revista de Administração

Contemporânea, v. 15, n. 4. p. 650-669, 2011.

OLIVEIRA, P. H. D. et al. Gestão do conhecimento orientada para a estratégia de inovação de produtos tecnológicos: o caso da Invent Vision. Revista de Administração e Inovação, v. 9, n. 4, p. 2012.

PATTON, M. Q. Qualitative research. Wiley Online Library, 2005.

PERIN, M. G. et al. O Impacto da formação gerencial no desempenho organizacional à luz da abordagem de competências. Brazilian Business Review, v. 6, n. 1, p. 104-120, 2009.

PORTER, M. E. Competitive advantage: creating and sustaining superior performance. New York, Free Press; Collier Macmillan, 1985.

RAZOUK, A. High-performance work systems and performance of French small-and medium-sized enterprises: examining causal order. International Journal of Human Resource Management, v. 22, n. 02, p. 311-330, 2011.

RICHARD, P. J. et al. Measuring organizational performance: towards methodological best practice. Journal of Management, v. 35, n. 3, p. 718-804, 2009. 
SANTOS, D. F. L.; BASSO, L. F. C.; KIMURA, H. A estrutura da capacidade de inovar das empresas brasileiras: uma proposta de construto. Revista de Administração e Inovação, v. 9, n. 3, p. 2012.

SHAW, J. D.; PARK, T. Y.; KIM, E. A resource-based perspective on human capital losses, hrm investments, and organizational performance. Strategic Management Journal, v. 34, n. 5, p. 572-589, 2013.

SUN, L.-Y.; ARYEE, S.; LAW, K. S. High-performance human resource practices, citizenship behavior, and organizational performance: a relational perspective. Academy of Management Journal, v. 50, n. 3, p. 558-577, 2007.

TEECE, D. J.; PISANO, G. P.; SHUEN, A. Dynamic capabilities and strategic management. Strategic Management Journal, v. 18, n. 7, p. 509-533, 1997.

UBEDA, C. L.; SANTOS, F. C. A. Os principais desafios da gestão de competências humanas em um instituto público de pesquisa. Gestão e Produção, v. 15, n. 1, p. 189-99, 2008 .

VENKATRAMAN, N.; RAMANUJAM, V. Measurement of business performance in strategy research: a comparison of approaches. Academy of Management Review, v. 11, n. 4, p. $801-814,1986$.

WRIGHT, P. M. et al. The relationship between HR practices and firm performance: examining causal order. Personnel Psychology, v. 58, n. 2, p. 409-446, 2005.

WRIGHT, P. M.; MCMAHAN, G. C. Theoretical perspectives for strategic human resource management. Journal of Management, v. 18, n. 2, p. 295-320, 1992.

WRIGHT, P. M.; MCMAHAN, G. C.; MCWILLIAMS, A. Human resources and sustained competitive advantage: a resource-based perspective. International Journal of Human Resource Management, v. 5, n. 2, p. 301-326, 1994.

ZEN, A. C.; FRACASSO, E. M. Recursos, competências e capacidade de inovação: um estudo de múltiplos casos na indústria eletro-eletrônica no Rio Grande do Sul. Revista de Administração e Inovação, v. 9, n. 4, p. 177-201, 2012. 
APPENDIX 1 - SELECTED ARTICLES AND RESULTS

\begin{tabular}{|c|c|c|c|c|c|c|c|}
\hline Authors & Strategy & Observation & Sector & HRM Dimensions & Resources & $\begin{array}{l}\text { Performance } \\
\text { Dimensions }\end{array}$ & Result \\
\hline $\begin{array}{l}\text { Abbade, Zanini and } \\
\text { Souza (2012). }\end{array}$ & Transversal & 123 companies & Several & & Learning orientation & Financial & Positive*** \\
\hline $\begin{array}{l}\text { Ferreira and Martinez } \\
\text { (2011) }\end{array}$ & Transversal & $\begin{array}{l}440 \text { employees of } \\
\text { companies }\end{array}$ & Services & & Human capital & Operational & Positive*** \\
\hline $\begin{array}{l}\text { Gomel and Sbragia } \\
\text { (2011) }\end{array}$ & Transversal & 488 companies & Software & Competencies & & Financial & Positive* \\
\hline Jabbour et al. (2012) & Transversal & 75 companies & Auto Parts & Cooperative & & Operational & Positive** \\
\hline $\begin{array}{l}\text { Maciel and Camargo } \\
\text { (2009) }\end{array}$ & Transversal & 119 companies & Retail clothing & Cooperative & & $\begin{array}{l}\text { Financial and } \\
\text { Operational }\end{array}$ & Positive* \\
\hline $\begin{array}{l}\text { Melo and Domenico } \\
\text { (2012) }\end{array}$ & Transversal & $\begin{array}{l}1 \text { bank and } 271 \\
\text { branches }\end{array}$ & Finance & & $\begin{array}{l}\text { Organizational } \\
\text { values }\end{array}$ & $\begin{array}{l}\text { Financial and } \\
\text { Operational }\end{array}$ & Positive* \\
\hline $\begin{array}{l}\text { Menezes, Guimarães } \\
\text { and Bido (2011) }\end{array}$ & Transversal & 266 individuals & Power & & Learning culture & Operational & Positive*** \\
\hline $\begin{array}{l}\text { Perin, Sampaio and } \\
\text { Hooley (2007) }\end{array}$ & Transversal & 293 companies & $\begin{array}{l}\text { Manufacturing and } \\
\text { services }\end{array}$ & Cooperative & & Operational & Positive** \\
\hline El-Kouba et al. (2009) & $\begin{array}{l}\text { Longitudinal } \\
\text { case study }\end{array}$ & 1 company & Communication & Competencies & & $\begin{array}{l}\text { Financial and } \\
\text { Operational }\end{array}$ & Positive $^{b}$ \\
\hline $\begin{array}{l}\text { Moori and Domenek } \\
\text { (2007) }\end{array}$ & $\begin{array}{l}\text { Longitudinal } \\
\text { case study }\end{array}$ & 1 company & Pulp and paper & $\begin{array}{l}\text { Opportunity to } \\
\text { contribute }\end{array}$ & & Operational & Positive $^{\mathrm{a}}$ \\
\hline Perin et al. (2009) & Case study & 3 companies & $\begin{array}{l}\text { Logging and } \\
\text { appliances }\end{array}$ & Competencies & & Operational & Positive $^{\mathrm{a}}$ \\
\hline $\begin{array}{l}\text { Ubeda and Santos } \\
(2008)\end{array}$ & $\begin{array}{l}\text { Longitudinal } \\
\text { case study }\end{array}$ & 1 Study Centre & $\begin{array}{l}\text { Research } \\
\text { institution }\end{array}$ & Competencies & & Operational & $\begin{array}{l}\text { Not } \\
\text { conclusive }\end{array}$ \\
\hline $\begin{array}{l}\text { Kirjavainen et al. } \\
(2010)\end{array}$ & Case study & 1 company & $\mathrm{B} 2 \mathrm{~B}$ & $\begin{array}{l}\text { Opportunity to } \\
\text { contribute }\end{array}$ & & Operational & $\begin{array}{l}\text { Not } \\
\text { conclusive }\end{array}$ \\
\hline Oliveira et al. (2012) & Case study & 1 company & Eletronics & & $\begin{array}{l}\text { Knowledge } \\
\text { management }\end{array}$ & Operational & $\begin{array}{l}\text { Not } \\
\text { conclusive }\end{array}$ \\
\hline $\begin{array}{l}\text { Zen and Fracasso } \\
\text { (2012) }\end{array}$ & Case study & 3 companies & Eletronics & \begin{tabular}{|l|} 
HR results \\
management
\end{tabular} & & Operational & $\begin{array}{l}\text { Not } \\
\text { conclusive }\end{array}$ \\
\hline $\begin{array}{l}\text { Santos, Basso and } \\
\text { Kimura (2012) }\end{array}$ & Transversal & 2116 companies & Several & $\begin{array}{l}\text { Results of R\&S } \\
\text { Practices of T\&D }\end{array}$ & & Financial & $\begin{array}{l}\text { Not } \\
\text { conclusive }\end{array}$ \\
\hline
\end{tabular}

: Qualitative studies without statistical test.

b. No information on the level of significance

$* \mathrm{p}<0.05 ; * *_{\mathrm{p}}<0.01 ; * * \mathrm{p}<0.001$ 